УДК 159.923:305:316.6

DOI https://doi.org/10.26661/2310-4368/2020-2-14

\title{
ОЦНКА ЕФЕКТИВНОСТІ КОМПЛЕКСНОЇ СИСТЕМИ СІМЕЙНОГО КОНСУЛЬТУВАННЯ ПОРУШЕНЬ ЖИТТЕДІЯЛЬНОСТІ РОДИНИ В РАЗІ АДЮЛЬТЕРУ
}

\author{
Бондар C. C. \\ аспірантка кафедри психології \\ Інститут підготовки кадрів державної служби зайнятості Украйни \\ вул. Нововокзальна, 17, Київ, Україна \\ orcid.org/0000-0002-9842-0470 \\ sveta12004@ukr.net,bondar.svetlana30@gmail.com
}

\author{
Ключові слова: адюльтер, \\ подружня взаємодія, \\ життедіяльність та \\ функиіонування родини, \\ сімейна криза та конфлікт.
}

Стаття присвячена оцінюванню ефективності комплексної системи сімейного консультування (психокорекції) порушень життєдіяльності родини в разі адюльтеру. Досліджено 90 пар у «кризовому віці браку» 3 наявністю адюльтеру. У респондентів виявлено слабку та помірну тривожність без ознак стомлюваності, слабкості, зниження працездатності. Власний стан критичний без заперечення психологічного конфлікту $(\mathrm{p}<0,05)$. Встановлено зменшення насиченості емоційних переживань щодо адюльтеру, бажання розмовляти на тему адюльтеру, зменшення явищ адинамії та вегетативносоматичних порушень $(\mathrm{p}<0,05)$.

Клінічним опитувальником оцінки невротичних станів виявлено зміни астенічних проявів, серед яких слід назвати нівелювання дратівливості та «втоми, що не шукає спокою», проте пасивність та порушення сну (поверхневий, тривожний, труднощі засинання й прокидання) збереглися у слабкому ступені вираження $(\mathrm{p}<0,05)$. Наявне істеричне коло реагування змінилося у бік відповідальних поведінкових паттернів без обвинувачень навколишніх, акцентування уваги на себе, отримання користі від кризи (первинна вигода) та зменшення нарцисових задоволень (вторинна вигода). Поведінка та соматичний стан характеризувалися як такі, що спрямовані на збереження душевного конфлікту без витіснення у соматичну сферу ( $<<0,05)$. Вищевикладене підтверджується факторним аналізом, яким виявлено зниження соматогенного психологічного реагування, за такими трьома факторами: тривоги та астенії; власне істеричне реагування; депресивнофобічний регістр (вегетативні прояви) (р<0,05).

Методикою «Визначення наявності та вираження комплексу меншовартості» у респондентів виявлено відновлену здатність самостійно вирішувати проблеми, кількість яких суб'єктивно значно зменшилась $(p<0,05)$. Методикою «Спілкування в сім’і» встановлено поліпшення відносин та спілкування у родині0 особливо у тих парах, які мали меншій стаж браку. Проте пари, які мали більший стаж сімейного життя, у сукупності 3 адюльтером мали уповільнення відновлення стосунків та меншу динаміку відновлення родинної взаємодії ( $<<0,05)$. 


\title{
EVALUATION OF THE EFFICIENCY OF THE COMPLEX SYSTEM OF FAMILY COUNSELING OF DYSFUNCTION OF FAMILY LIFE DUE TO ADULTERY
}

\author{
Bondar S. S. \\ Postgraduate Student at the Department of Psychology \\ Ukrainian State Employment Service Training Institute \\ Novovokzalna str., 17, Kyiv, Ukraine \\ orcid.org/0000-0002-9842-0470 \\ sveta12004@ukr.net,bondar.svetlana30@gmail.com
}

Key words: adultery, family interaction, family life and functioning, family crisis and conflict.

\begin{abstract}
The article is devoted to the evaluation of the efficiency of the complex system of family counseling (psycho-correction) of dysfunction of family life due to adultery. The study was conducted among 90 couples in the "crisis age of marriage with adultery in the family history. The respondents were found "light" or "moderate" anxiety without symptoms of fatigability, weakness, decreased functioning. The own state is critical without objection to conflict $(\mathrm{p}<0.05)$. It was found the relaxation of emotional experiences intensity due to adultery, wish to "speak" about adultery, decrease of adynamia symptoms and vegetative-somatic disorders $(p<0,05)$.

According to clinical form in assessment of neurotic states, it was found changes of asthenic manifestations, including leveling of irritability and "restless fatigue", but passivity and disturbance of sleep (superficial, anxious, difficulties falling asleep and awaking) are remained in light form of intensity ( $<<0.05)$. Therefore, the present hysterical reactions were changed towards crucial behavioral patterns without "accusations" of others, focusing on themselves, getting "gains" from the crisis (primary gain) and decrease of narcissistic pleasures (secondary gain). Behavior and somatic state were described as directed to "maintenance of mental conflict" not exclusion to somatic sphere" $(\mathrm{p}<0.05)$. The above is verified by factor analysis which found out weakness of somatogenic psychological response under three factors: a) anxieties and asthenias; b) actually hysterical response; c) depressive-phobic records (vegetative manifestations) $(\mathrm{p}<0.05)$.

The method "Determining the presence and intensity of the inferiority complex" the respondents were found a restored ability to solve problems independently, number of which significantly decreased $(p<0.05)$. The method "Family interaction" determined the improvement of family relations and interaction especially in those couples who has less experience of marriage. However, couples with more family life experience in combination with adultery had a slowdown rebuilding relations and less dynamic to restore family interaction $(\mathrm{p}<0.05)$.
\end{abstract}

Постановка проблеми. Актуальною проблемою сімейного консультування $€$ надання сучасної психологічної та психокорекційної допомоги родинам. Особливо складною є допомога родинам 3 порушення функціонування внаслідок ситуації адюльтеру, яка створює психотравмуючу ситуацію для сім’ї, призводячи до подружньої дезадаптації. Як алгоритм роботи із сім'єю, яка переживає кризу, H.I. Оліфірович зі співавторами (2006 рік) пропонує модель консультування 3 таких етапів [1].

1) Виявлення уявлень членів сім’ї про характер пережитих труднощів.

2) Уточнення фактів сімейного життя та особливостей іiі динаміки. Аналіз сімейної історії для адекватного розуміння ситуації, що склалася.
3) Зворотній зв’язок від консультанта сім’ї, що включає повідомлення про те, як консультант розуміє проблему, відображення його власних почуттів і переживань, підтримка сім’ї в їх бажанні отримати психологічну допомогу.

4) Визначення проблемного поля родини. На цьому етапі здійснюється ідентифікація проблем цієї сім’ї, висуваються припущення щодо причин виниклих труднощів, механізмів їх виникнення та розвитку, за необхідності збираються додаткові відомості для перевірки висунутих гіпотез. Підсумком цього етапу $\epsilon$ узгодження уявлень психолога й членів сім’ї про наявні проблеми, а також постановка реалістичних цілей. 
5) Опрацювання почуттів членів сім'ї, пов’язаних 3 пережитою кризою.

6) Ідентифікація альтернатив. На цій стадії з'ясовуються й відкрито обговорюються можливі альтернативи рішення проблем. Консультант спонукає членів сім'ї проаналізувати всі можливі варіанти, висуває додаткові альтернативи, не нав'язуючи своїх рішень.

7) Планування. На цій стадії здійснюється критичне оцінювання вибраних альтернатив. Консультант допомагає родині розібратися, які альтернативи підходять і є реалістичними 3 точки зору попереднього досвіду та актуальною готовністю змінитися. Перевірка реалістичності вибраного рішення (рольові ігри, «репетиція» дій тощо).

8) Діяльність. На цьому етапі відбувається послідовна реалізація плану вирішення проблем сім'ї, особливої важливості набуває підтримка консультантом членів сім'ї.

Як правило, робота із сім'єю, яка переживає кризу, здійснюється у форматі короткостроковій терапії (від 1 до 20 зустрічей). Пропонована нами модель консультування дає можливість сімейному психологу гнучко використовувати й модифікувати як послідовність, так і зміст етапів 3 урахуванням специфіки конкретної сім'ї.

3 огляду на те, що психосоціальні та особистісні причин адюльтеру багатогранні, вони знижують демонстрування додаткових емпатичних здібностей, співпереживання та співчуття, що виснажує психічний ресурс чоловіка та дружини (Е.Г. Ейдеміллер, 2008 рік) [2]. Наукових праць, присвячених вивченню психокорекції подружньої дезадаптації, пов'язаної з позашлюбними зв'язками, налічуються одиниці, й загалом ця проблема $є$ мало вивченою і недостатньо висвітленою в літературі (О.А. Мєшковська, 2005 рік) [3]. Н.I. Оліфірович зі співавторами (2006 рік) зазначають, що аналіз феномена зради та надання психологічної допомоги слід здійснювати на трьох рівнях, а саме індивідуальному, що передбачає роботу з одним з подружжя, де увага приділяється опрацюванню внутрішньо особистісних проблем, пов'язаних $з$ його патохарактерологічними особливостями; микросистемному, що передбачає роботу з подружньою парою, а саме визначення характеру порушень подружніх відносин, що призвели до зради, і корекцію дисфункціональних паттернів взаємодії шлюбних партнерів; макрорівні, на якому досліджуються інші члени сім'і (діти, прабатьки), рекомендується проводити сімейну терапію [1].

Аналіз останніх досліджень та публікацій. Огляд джерел свідчить про широку палітру досліджень проблем сім'ї. Так, феномен любові вивчали Ж.-П. Сартр, Л. Бінсвангер, М. Босс, В. Франкл, Е. Фромм, І. Ялом, А. Маслоу, порушення любов- них взаємин, а саме невротичну потребу в любові, вивчав К. Хорні, стосунки подружньої залежності - Н.Г. Гаранян, А.Б. Холмогорова. Форми залежної (невротичної) любові, зокрема токсичну любов, досліджував П. Меллоді, любов-залежність - В. Сатір, любов-манію - С. Піл, А. Бродскі, любов-прихильність - П. Шавер, К. Хейзан, Д. Бредшоу [4]. Вивчаються психоемоційні проблеми сімейного функціонування за різних стилів сімейної взаємодії (Prib, Bondar, 2019) [5]. Хоча різні аспекти подружньої дезадаптації, що зумовлена позашлюбними зв'язками, були предметом досліджень учених, залишається поза увагою та до останнього не з'ясована ефективність заходів консультування сімейних пар в разі адюльтеру.

Не вивчено провідні чинники, що відновлюють родину, внаслідок чого не розроблено ефективні системи психотерапевтичної корекції, психоемоційного супроводу родини в умовах кризи. До не вирішених раніше частин проблеми можна віднести недостатню вивченість ефективності систем допомоги та заходів психокорекції сімейних пар в разі адюльтеру.

Мета статті полягає в дослідженні ефективності впровадження комплексної системи сімейного консультування (психокорекції) порушень життєдіяльності родини в разі адюльтеру. Задачею статті $\epsilon$ виявлення особливостей психоемоційного та індивідуально-психологічного реагування й сімейного спілкування під час консультування родини в разі адюльтеру.

Методи та матеріал дослідження. 3 дотриманням принципів деонтології проведено обстеження 90 подружніх пар. У процесі оцінювання ефективності запропонованої КС-СКА вивчалися кількісні та якісні характеристики, а саме досліджені невротичні стани за допомогою клінічного опитувальника виявлення й оцінювання невротичних станів (К.К. Яхін, В.Д. Менделевич, 2005 рік) [6]; особливості індивідуально-психологічного реагування за допомогою методики «Визначення наявності та вираження комплексу меншовартості» (Н.П. Фетіскін, В.В. Козлов, Г.М. Мануйлов, 2000 рік) [7]; спілкування у родині за допомогою методики «Спілкування в сім'ї» (Ю.Е. Альошина, Л.Я. Гозман, Е.М. Дубовска, 2007 рік) [8]. Оцінювання ефективності (ОЕ) розробленої КС-СКА здійснено шляхом порівняльного аналізу показників, отриманих під час дослідження 90 подружніх пар трьох підгруп КГА, що представлено на рис. 1.

У групу ОЕ-КГА1, ОЕ-КГА2, ОЕ-КГАЗ увійшли пари, які надали інформаційну згоду на участь у заходах психологічного консультування та психокорекції в рамках розробленої комплексної системи. Періодом оцінювання ефективності КС-СКА вибрано 6 місяців від початку психокорекційної роботи. Цей період вибрано з огляду 


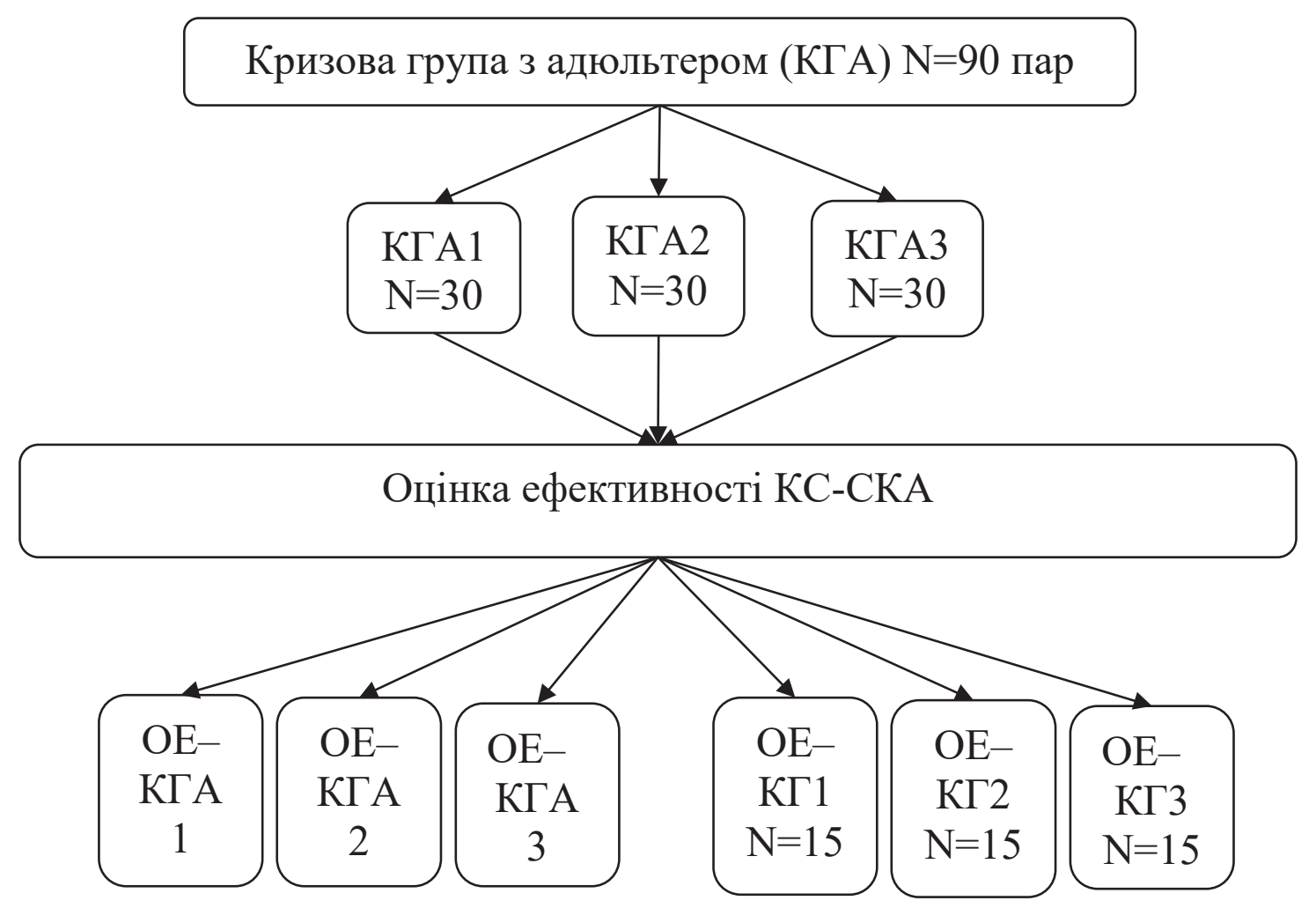

Рис. 1. Розподіл обстежених на групи дослідження на етапі оцінювання ефективності КС-СКА

на те, що через 6 місяців можна оцінити результати заходів з урахуванням «звикання» до заходів та часткової втрати первинного ефекту. У групу OE-КГ1, ОЕ-КГ2, ОЕ-КГЗ увійшли пари, які відмовилися від участі у заходах психологічного консультування та психокорекції в рамках розробленої комплексної системи, проте дали згоду на повторне обстеження стану життєдіяльності родини через 6 місяців. Аналіз, оброблення й підрахунок процентних характеристик і коефіцієнтів кореляції здійснювалися за допомогою програми SPSS 10.0.5 for Windows (А. Бююль, 2002 рік) [9].

Виклад основного матеріалу дослідження. На першому етапі проводилось оцінювання ефективності невротичних станів (клінічний опитувальник виявлення й оцінки невротичних станів, КК. Яхін, В.Д. Менделевич, 2005 рік) [6]. Невротичні стани у респондентів у групах оцінки ефективності представлено у табл. 1 .

3 даних, представлених у табл. 1, видно, що за шкалою тривоги виявлено такі показники: у чоловіків ОЕ-КГА 1 - 13,3\%, ОЕ-КГА 2 - 13,3\%, ОЕ-КГА 3 - 6,7\%, у жінок ОЕ-КГА 1 - 13,3\%, ОЕКГА $2-6,7 \%$, ОЕ-КГА $3-13,3 \%(\mathrm{p}<0,05)$. Тривожність у ОЕ-КГА класифікувалась як слабка без внутрішнього неспокою. Не виявлено виражених ознак підвищеної стомлюваності, слабкості, зниження працездатності $(\mathrm{p}<0,05)$, також власний стан сприймається усвідомлено без заперечення психологічного конфлікту $(\mathrm{p}<0,05)$. Тривожність у ОЕ-КГ виглядала таким чином: у чоловіків OEКГ 1 - 26,7\%, ОЕ-КГ2 - 20,0\%, ОЕ-КГ 3 - 20,0\%, у жінок ОЕ-КГ $1-20,0 \%, \mathrm{OE}-\mathrm{K} Г 2-33,3 \%$, OEКГЗ - 33,3\% $(\mathrm{p}<0,05)$. Тривожність класифікувалась як помірна та характеризувалася схильністю до сприйняття широкого кола ситуацій як загрозливих власної самооцінці, престижу, самоповазі. Респонденти виявляли чутливість до ймовірних невдач, які можуть трапитися, знижений фон настрою, нав'язливі думки або дії, спрямовані на подолання власних страхів.

За шкалою невротичної депресії виявлено такі показники: у чоловіків ОЕ-КГА $1-6,7 \%$, OEКГА 2 - 13,3\%, ОЕ-КГА 3 - 6,7\%, у жінок ОЕКГА 1 - 13,3\%, ОЕ-КГА $2-6,7 \%$, ОЕ-КГА $3-13,3 \%$ $(\mathrm{p}<0,05)$. Особи ОЕ-КГА 3 невротичною тривожністю характеризувалися зменшенням насиченості емоційних переживань щодо адюльтеру; бажанням розмовляти на тему адюльтеру. У чоловіків та жінок переважали рівний настрій, зменшення явищ адинамії, зменшення вегетативно-соматичних порушень. Невротична депресія у $\mathrm{OE}-\mathrm{KГ}$ виглядала таким чином: у чоловіків $\mathrm{OE}-$ КГ 1 - 20,0\%, ОЕ-КГ2 - 26,7\%, ОЕ-КГ $3-26,7 \%$, у жінок ОЕ-КГ $1-26,7 \%$, ОЕ-КГ 2 - 20,0\%, ОЕКГЗ - 33,3\% $(\mathrm{p}<0,05)$. У досліджених ОЕ-КГ відзначалося збереження тужливого ставлення до майбутнього та загалом депресивного фону, 
Таблиця 1

Невротичні стани у респондентів у групах оцінки ефективності

\begin{tabular}{|c|c|c|c|c|c|c|c|c|c|c|}
\hline \multirow[t]{2}{*}{ Шкали } & \multirow[t]{2}{*}{$\mathrm{C}$} & \multicolumn{3}{|c|}{ ОЕ-КГА1 } & \multicolumn{3}{|c|}{ ОЕ-КГА2 } & \multicolumn{3}{|c|}{ ОЕ-КГАЗ } \\
\hline & & $\mathbf{N}$ & $\%$ & $\pm \mathbf{m}$ & $\mathbf{N}$ & $\%$ & $\pm \mathbf{m}$ & $\mathbf{N}$ & $\%$ & $\pm \mathbf{m}$ \\
\hline \multirow[t]{2}{*}{ Шкала тривоги } & Ч & 2 & 13,3 & 3,4 & 2 & 13,3 & 3,4 & 1 & 6,7 & 2,5 \\
\hline & Ж & 2 & 13,3 & 3,4 & 1 & 6,7 & 2,5 & 2 & 13,3 & 3,4 \\
\hline \multirow{2}{*}{$\begin{array}{l}\text { Шкала невротичної } \\
\text { депресії }\end{array}$} & 4 & 1 & 6,7 & 2,5 & 2 & 13,3 & 3,4 & 1 & 6,7 & 2,5 \\
\hline & Ж & 2 & 13,3 & 3,4 & 1 & 6,7 & 2,5 & 2 & 13,3 & 3,4 \\
\hline \multirow[t]{2}{*}{ Шкала астенії } & $\mathrm{Y}$ & 2 & 13,3 & 3,4 & 2 & 13,3 & 3,4 & 1 & 6,7 & 2,5 \\
\hline & Ж & 3 & 20,0 & 4,0 & 1 & 6,7 & 2,5 & 2 & 13,3 & 3,4 \\
\hline \multirow{2}{*}{$\begin{array}{l}\text { Шкала істеричного } \\
\text { типу реагування }\end{array}$} & $\mathrm{Y}$ & 1 & 6,7 & 2,5 & 2 & 13,3 & 3,4 & 1 & 6,7 & 2,5 \\
\hline & Ж & 2 & 13,3 & 3,4 & 2 & 13,3 & 3,4 & 1 & 6,7 & 2,5 \\
\hline \multirow{2}{*}{$\begin{array}{l}\text { Шкала обсессивно- } \\
\text { фобічних порушень }\end{array}$} & 4 & 2 & 13,3 & 3,4 & 1 & 6,7 & 2,5 & 2 & 13,3 & 3,4 \\
\hline & Ж & 1 & 6,7 & 2,5 & 2 & 13,3 & 3,4 & 1 & 6,7 & 2,5 \\
\hline \multirow{2}{*}{$\begin{array}{l}\text { Шкала вегетативних } \\
\text { порушень }\end{array}$} & $\mathrm{Y}$ & 2 & 13,3 & 3,4 & 3 & 20,0 & 4,0 & 2 & 13,3 & 3,4 \\
\hline & Ж & 1 & 6,7 & 2,5 & 1 & 6,7 & 2,5 & 3 & 20,0 & 4,0 \\
\hline \multirow[t]{2}{*}{ Усього } & 4 & 15 & \multicolumn{2}{|c|}{100,0} & 15 & \multicolumn{2}{|c|}{100,0} & 15 & \multicolumn{2}{|c|}{100,0} \\
\hline & Ж & 15 & \multicolumn{2}{|c|}{100,0} & 15 & \multicolumn{2}{|c|}{100,0} & 15 & \multicolumn{2}{|c|}{100,0} \\
\hline Шкали & $\mathrm{C}$ & \multicolumn{3}{|c|}{ ОЕ-КГ1 } & \multicolumn{3}{|c|}{ OE-КГ2 } & \multicolumn{3}{|c|}{ ОE-КГЗ } \\
\hline \multirow[t]{2}{*}{ Шкала тривоги } & 4 & 4 & 26,7 & 4,4 & 3 & 20,0 & 4,0 & 3 & 20,0 & 4,0 \\
\hline & Ж & 3 & 20,0 & 4,0 & 5 & 33,3 & 4,7 & 5 & 33,3 & 4,7 \\
\hline \multirow{2}{*}{$\begin{array}{l}\text { Шкала невротичної } \\
\text { депресії }\end{array}$} & 4 & 3 & 20,0 & 4,0 & 4 & 26,7 & 4,4 & 4 & 26,7 & 4,4 \\
\hline & Ж & 4 & 26,7 & 4,4 & 3 & 20,0 & 4,0 & 5 & 33,3 & 4,7 \\
\hline \multirow[t]{2}{*}{ Шкала астенії } & 4 & 4 & 26,7 & 4,4 & 4 & 26,7 & 4,4 & 4 & 26,7 & 4,4 \\
\hline & Ж & 3 & 20,0 & 4,0 & 2 & 13,3 & 3,4 & 6 & 40,0 & 4,9 \\
\hline \multirow{2}{*}{$\begin{array}{l}\text { Шкала істеричного } \\
\text { типу реагування }\end{array}$} & Ч & 5 & 33,3 & 4,7 & 3 & 20,0 & 4,0 & 5 & 33,3 & 4,7 \\
\hline & Ж & 4 & 26,7 & 4,4 & 5 & 33,3 & 4,7 & 4 & 26,7 & 4,4 \\
\hline \multirow{2}{*}{$\begin{array}{l}\text { Шкала обсессивно- } \\
\text { фобічних порушень }\end{array}$} & Ч & 3 & 20,0 & 4,0 & 4 & 26,7 & 4,4 & 5 & 33,3 & 4,7 \\
\hline & Ж & 4 & 26,7 & 4,4 & 3 & 20,0 & 4,0 & 4 & 26,7 & 4,4 \\
\hline \multirow{2}{*}{$\begin{array}{l}\text { Шкала вегетативних } \\
\text { порушень }\end{array}$} & 4 & 3 & 20,0 & 4,0 & 4 & 26,7 & 4,4 & 5 & 33,3 & 4,7 \\
\hline & Ж & 5 & 33,3 & 4,7 & 4 & 26,7 & 4,4 & 4 & 26,7 & 4,4 \\
\hline \multirow[t]{2}{*}{ Усього } & 4 & 15 & & & 15 & & & 15 & & \\
\hline & Ж & 15 & & & 15 & & & 15 & & \\
\hline
\end{tabular}

ймовірність помилки першого роду, рівень статистичної значимості між показниками: $p<0,05$ (достовірно значущі відмінності); $\mathrm{C}-\mathrm{cmaть}$

що проявлявся в наявності сімейної кризи, що травмує, «втечею в роботу». Перебіг невротичної депресії був нестабільним зі сльозливістю. Загалом невротична симптоматика супроводжувалася скаргами на зниження активності, порушення сну, відсутність радості від життя. Придушення негативних емоцій супроводжувалося вегетативно-соматичними розладами (коливання артеріального тиску, серцебиття, запаморочення, дисфункції шлунково-кишкового тракту).

За шкалою астенії виявлено такі показники: у чоловіків ОЕ-КГА1 - 13,3\%, ОЕ-КГА2 - 13,3\%, ОЕ-КГА3 - 6,7\%, у жінок ОЕ-КГА1 - 20,0\%, ОЕ-КГА2 - 6,7\%, ОЕ-КГА3 - 13,3\% $(\mathrm{p}<0,05)$. У OЕ-КГА таки астенічні прояви, як дратівливість, «втома, що не шукає спокою», не виявлено. У слабкому ступені вираження виявлено пасивність та порушення сну. У деяких респондентів зберігався поверхневий та тривожний сон, труднощі засинання й прокидання. Астенія у ОЕ-КГ виглядала таким чином: у чоловіків ОЕ-КГ1 26,7\%, ОЕ-КГ2 - 26,7\%, ОЕ-КГ3 - 26,7\%, у жінок $\mathrm{OE}-\mathrm{K} \Gamma 1-20,0 \%, \mathrm{OE}-\mathrm{K} Г 2-13,3 \%, \mathrm{OE}-\mathrm{K} \Gamma 3-$ $40,0 \%(\mathrm{p}<0,05)$. У ОЕ-КГ збереглися такі астенічні прояви, як підвищена стомлюваність, ослаблення або втрата здатності до тривалої фізичної та розумової напруги. Виявлено прояви астенічного кола, а саме емоційну нестійкість, образливість, вразливість, слабкість, підвищену стомлюваність, труднощі концентрації уваги.

За шкалою істеричного типу реагування виявлено такі показники: у чоловіків ОЕ-КГА 1 - 6,7\%, ОЕ-КГА 2 - 13,3\%, ОЕ-КГА 3 - 6,7\%, у жінок OEКГА 1 - 13,3\%, ОЕ-КГА2 - 13,3\%, ОЕ-КГА 3 $6,7 \%(\mathrm{p}<0,05)$. У ОЕ-КГА аналіз істеричного кола реагування виявив зменшення поведінкових пат- 
тернів на заклик до навколишнього світу для звернення уваги до себе. У клінічній картині істеричного реагування сімейна криза зменшила прояв як мета й шлях для отримання користі (первинна користь від кризи). Паралельно зменшилися нарцисові задоволення використання кризи (вторинна користь від кризи).

Істеричне реагування у ОЕ-КГ виглядало таким чином: у чоловіків ОЕ-КГ 1 - 33,3\%, ОЕКГ2 - 20,0\%, ОЕ-КГ3 - 33,3\%, у жінок ОЕКГ 1 - 26,7\%, ОЕ-КГ2 - 33,3\%, ОЕ-КГ3 - 26,7\% $(\mathrm{p}<0,05)$. У досліджених ОЕ-КГ аналіз істеричного кола реагування дав змогу відзначити збереження душевного конфлікту у кризовий період родини та витіснення його у соматичну симптоматику. Збереглися установки на такі символічні заперечення: «від мене нічого більше не можна вимагати», «зі мною трапилося лихо», «тепер нарешті про мене будуть піклуватися».

За шкалою обсессивно-фобічних порушень виявлено такі показники: у чоловіків ОЕКГА 1 - 13,3\%, ОЕ-КГА $2-6,7 \%$, ОЕ-КГА $3-13,3 \%$, у жінок ОЕ-КГА 1 - 6,7\%, ОЕ-КГА 2 - 13,3\%, ОЕКГА 3 - 6,7\% $(\mathrm{p}<0,05)$. У респондентів ОЕ-КГА аналіз обсессивно-фобічного кола реагування виявив відсутність «небажаних уявлень», думок, спонукань.

Обсессивно-фобічні порушення у ОЕ-КГ виглядали таким чином: у чоловіків ОЕ-КГ1 20,0\%, ОЕ-КГ2 - 26,7\%, ОЕ-КГ3 - 33,3\%, у жінок OE-КГ1 - 26,7\%, ОЕ-КГ2 - 20,0\%, ОЕ-КГ3 $26,7 \%(\mathrm{p}<0,05)$. Обсессивно-фобічні порушення у ОЕ-КГ зберігали помірну тяжкість, що іноді приводило до порушень сімейного функціонування у рамках недовіри партнеру та очікування повторного адюльтеру.

За шкалою вегетативних порушень виявлено такі показники: у чоловіків ОЕ-КГА1 - 13,3\%, OЕ-КГА2 - 20,0\%, ОЕ-КГА3 - 13,3\%, у жінок OE-КГА 1 - 6,7\%, ОЕ-КГА 2 - 6,7\%, ОЕ-КГА 3 $20,0 \%(p<0,05)$. У досліджених ОЕ-КГА прояви вегетативних порушень на тлі психофізичного відновлення проявлялися не вираженими симптомами зниження концентрації уваги та працездатності. Вегетативні порушення у OE-КГ виглядали таким чином: у чоловіків ОЕ-КГ1 - 20,0\%, ОЕ-КГ2 - 26,7\%, ОЕ-КГ3 - 33,3\%, у жінок ОЕКГ 1 - 33,3\%, ОЕ-КГ 2 - 26,7\%, ОЕ-КГ3 - 26,7\% $(\mathrm{p}<0,05)$. У досліджених ОЕ-КГ зберігалися зниження активності, боязкість, слабкість, коливання настрою, мушки перед очима, розлади сну, тремтіння пальців, пригніченість, тиск у голові, головні болі, періодичні запаморочення, відсутність апетиту, шлунково-кишкові скарги, порушення потенції або лібідо.

Факторний аналіз показників шкал опитувальника виявлення та оцінки невротичних станів встановив, що у досліджених ОЕ-КГА загалом є зниження соматогенного психологічного реагування. Таке зниження спостерігалося за трьома факторами, а саме за шкалами тривоги й астенії (симптоми тривоги, стомлюваності, виснаження); істеричного реагування; депресивно-фобічного регістру (вегетативні прояви). Дослідженим OEКГ притаманне високе соматогенне психологічне реагування $з$ астенічною симптоматикою. За провідними факторами це проявлялося таким чином: вегетативні прояви конверсії (нудота, тахікардія), симптоми виснаження (слабкість, зниження ініціативи), тривожно-фобічні прояви.

Особливості психологічного реагування пари на адюльтер та їх роль у генезі розвитку порушення життєдіяльності сім’ї (методика «Діагностика комплексу меншовартості», Н.П. Фетискін зі співавторами (2000 рік) [7]) представлено у табл. 2.

3 представлених у табл. 2 даних видно, що від 0-40 балів у чоловіків ОЕ-КГА1 - 66,7\%, ОЕКГА 2 - 66,7\%, ОЕ-КГА 3 - 66,7\%. Серед жінок: ОЕ-КГА 1 - 73,3\%, ОЕ-КГА 2 - 60,0\%, ОЕ-КГА 3 $73,3 \%(\mathrm{p}<0,05)$. У чоловіків ОЕ-КГ $1-13,3 \%$, ОЕКГ $2-13,3 \%$, ОЕ-КГ3 - 13,3\%, у жінок ОЕ-КГ1 $13,3 \%$, ОЕ-КГ $2-13,3 \%$, ОЕ-КГ $3-14,3 \%(\mathrm{p}<0,05)$. Респонденти ОЕ-КГ виявляли закомплексованість, оцінювали себе негативно, були зациклені на власних слабостях, недоліках, помилках, у OEКГА цих проявів не виявлено.

Від 41-80 балів у чоловіків ОЕ-КГА1 - 13,3\%, ОЕ-КГА 2 - 6,7\%, ОЕ-КГА 3 - 6,7\%. Серед жінок: ОЕ-КГА 1 - 6,7\%, ОЕ-КГА2 - 6,7\%, ОЕ-КГА 3 $13,3 \%(\mathrm{p}<0,05)$. У чоловіків ОЕ-КГ $1-6,7 \%, \mathrm{OE}-$ КГ $2-20,0 \%$, OЕ-КГ $3-20,0 \%$, у жінок ОЕ-КГ $1-$ $13,3 \%$, ОЕ-КГ $2-13,3 \%$, ОЕ-КГ3 - 14,3\% ( $<<0,05)$. Респонденти ОЕ-КГА виявляли здатність справитися 3 комплексами, у ОЕ-КГ ці здатності слабкі.

Від 81-130 балів у чоловіків ОЕ-КГА $1-13,3 \%$, ОЕ-КГА 2 - 13,3\%, ОЕ-КГА3 - 13,3\%. Серед жінок: ОЕ-КГА 1 - 13,3\%, ОЕ-КГА 2 - 13,3\%, ОЕ-КГА $3-13,3 \%(\mathrm{p}<0,05)$. У чоловіків ОЕ-КГ1 60,0\%, ОЕ-КГ 2 - 60,0\%, ОЕ-КГ3 - 46,7\%, у жінок $\mathrm{OE}-\mathrm{K} \Gamma 1-60,0 \%, \mathrm{OE}-\mathrm{K} Г 2$ - 60,0\%, ОЕ-КГ3 $50,0 \%(\mathrm{p}<0,05)$. Респонденти ОЕ-КГА виявляли здатність до самостійного вирішення комплексів, а їх кількість була незначна. У ОЕ-КГ самостійно комплекси не вирішували.

Від 131-150 балів у чоловіків ОЕ-КГА 1 - 6,7\%, ОЕ-КГА 2 - 13,3\%, ОЕ-КГА3 - 13,3\% (p<0,05), у жінок ОЕ-КГА 1 - 6,7\%, ОЕ-КГА 2 - 13,3\%, $\mathrm{OE}-\mathrm{K} Г А ~ 3-6,7 \%(\mathrm{p}<0,05)$. У чоловіків ОЕ-КГ1 20,0\%, ОЕ-КГ2 - 6,7\%, ОЕ-КГ3 - 20,0\%, у жінок ОЕ-КГ1 - 13,3\%, ОЕ-КГ2 - 13,3\%, ОЕ-КГ3 $21,4 \%(p<0,05)$. Респонденти ОЕ-КГА не мали, на відміну від ОЕ-КГ, помилкових уявлень щодо відсутності комплексів. 
Таблиця 2

Структура комплексу меншовартості у респондентів груп оцінювання ефективності

\begin{tabular}{|c|c|c|c|c|c|c|c|c|c|c|}
\hline \multirow[t]{2}{*}{ Бали } & \multirow[t]{2}{*}{$\mathbf{C}$} & \multicolumn{3}{|c|}{ ОЕ-КГА1 } & \multicolumn{3}{|c|}{ ОЕ-КГА2 } & \multicolumn{3}{|c|}{ ОЕ-КГАЗ } \\
\hline & & $\mathbf{N}$ & $\%$ & $\pm \mathbf{m}$ & $\mathbf{N}$ & $\%$ & $\pm \mathbf{m}$ & $\mathbf{N}$ & $\%$ & $\pm \mathbf{m}$ \\
\hline \multirow{2}{*}{$0-40$} & $\mathrm{Y}$ & 10,0 & 66,7 & 4,7 & 10,0 & 66,7 & 4,7 & 10,0 & 66,7 & 4,7 \\
\hline & Ж & 11,0 & 73,3 & 4,4 & 9,0 & 60,0 & 4,9 & 11,0 & 73,3 & 4,4 \\
\hline \multirow{2}{*}{$41-80$} & 4 & 2,0 & 13,3 & 3,4 & 1,0 & 6,7 & 2,5 & 1,0 & 6,7 & 2,5 \\
\hline & Ж & 1,0 & 6,7 & 2,5 & 2,0 & 13,3 & 3,4 & 1,0 & 6,7 & 2,5 \\
\hline \multirow{2}{*}{$81-130$} & 4 & 2,0 & 13,3 & 3,4 & 2,0 & 13,3 & 3,4 & 2,0 & 13,3 & 3,4 \\
\hline & Ж & 2,0 & 13,3 & 3,4 & 2,0 & 13,3 & 3,4 & 2,0 & 13,3 & 3,4 \\
\hline \multirow{2}{*}{$131-150$} & $\mathrm{Y}$ & 1,0 & 6,7 & 2,5 & 2,0 & 13,3 & 3,4 & 2,0 & 13,3 & 3,4 \\
\hline & Ж & 1,0 & 6,7 & 2,5 & 2,0 & 13,3 & 3,4 & 1,0 & 6,7 & 2,5 \\
\hline \multirow{2}{*}{ Усього } & $\mathrm{Y}$ & 15 & \multicolumn{2}{|c|}{100,0} & 15 & \multicolumn{2}{|c|}{100,0} & 15 & \multicolumn{2}{|c|}{100,0} \\
\hline & Ж & 15 & \multicolumn{2}{|c|}{100,0} & 15 & \multicolumn{2}{|c|}{100,0} & 15 & \multicolumn{2}{|c|}{100,0} \\
\hline Бали & $\mathbf{C}$ & \multicolumn{3}{|c|}{ ОЕ-КГА1 } & \multicolumn{3}{|c|}{ ОЕ-КГА2 } & \multicolumn{3}{|c|}{ ОЕ-КГАЗ } \\
\hline \multirow{2}{*}{$0-40$} & 4 & 2,0 & 13,3 & 3,4 & 2,0 & 13,3 & 3,4 & 2,0 & 13,3 & 3,4 \\
\hline & Ж & 2,0 & 13,3 & 3,4 & 2,0 & 13,3 & 3,4 & 2,0 & 14,3 & 3,5 \\
\hline \multirow{2}{*}{$41-80$} & $\mathrm{Y}$ & 1,0 & 6,7 & 2,5 & 3,0 & 20,0 & 4,0 & 3,0 & 20,0 & 4,0 \\
\hline & Ж & 2,0 & 13,3 & 3,4 & 2,0 & 13,3 & 3,4 & 2,0 & 14,3 & 3,5 \\
\hline \multirow{2}{*}{$81-130$} & Ч & 9,0 & 60,0 & 4,9 & 9,0 & 60,0 & 4,9 & 7,0 & 46,7 & 5,0 \\
\hline & Ж & 9,0 & 60,0 & 4,9 & 9,0 & 60,0 & 4,9 & 7,0 & 50,0 & 5,0 \\
\hline \multirow{2}{*}{$131-150$} & Ч & 3,0 & 20,0 & 4,0 & 1,0 & 6,7 & 2,5 & 3,0 & 20,0 & 4,0 \\
\hline & Ж & 2,0 & 13,3 & 3,4 & 2,0 & 13,3 & 3,4 & 3,0 & 21,4 & 4,1 \\
\hline \multirow{2}{*}{ Усього } & 4 & 15 & \multicolumn{2}{|c|}{100,0} & 15 & \multicolumn{2}{|c|}{100,0} & 15 & \multicolumn{2}{|c|}{100,0} \\
\hline & Ж & 15 & \multicolumn{2}{|c|}{100,0} & 15 & \multicolumn{2}{|c|}{100,0} & 15 & \multicolumn{2}{|c|}{100,0} \\
\hline
\end{tabular}

Спілкування у родині проаналізовано за методикою «Спілкування в сім’ї» (Ю.Е. Альошина зі співавторами, 2007 рік) [8]. Результати розподілу респондентів у групах оцінювання ефективності щодо спілкування у сім’ї відображено у табл. 3.

3 даних табл. 3 видно, що серед респондентів ОЕ-КГА параметр «Довіра у спілкуванні» мав такий вигляд: у чоловіків ОЕ-КГА $1-60,0 \%$, OE-КГА 2 - 60,0\%, OE-КГА 3 - 66,7\% (p<0,05), у жінок ОЕ-КГА 1 - 53,3\%, ОЕ-КГА 2 - 60,0\%, $\mathrm{OE}-$ КГА 3 - 60,0\% $(\mathrm{p}<0,05)$. У чоловіків ОЕКГ 1 - 40,0\%, OE-КГ2 - 46,7\%, ОЕ-КГ3 - 46,7\%, у жінок ОЕ-КГ 1 - 46,7\%, ОЕ-КГ2 - 53,3\%, OEКГ3 - 46,7\% (p<0,05). Параметр «Взаємоповага між подружжям» у чоловіків ОЕ-КГА1 - 46,7\%, OЕ-КГА2 - 66,7\%, ОЕ-КГА 3 - 53,3\% (p<0,05), у жінок ОЕ-КГА 1 - 53,3\%, ОЕ-КГА 2 - 60,0\%, OЕ-КГА 3 - 66,7\% $(\mathrm{p}<0,05)$. У чоловіків ОЕКГ 1 - 33,3\%, ОЕ-КГ2 - 26,7\%, ОЕ-КГ3 - 33,3\%, у жінок ОЕ-КГ $1-40,0 \%, \mathrm{OE}-\mathrm{K} Г 2-33,3 \%, \mathrm{OE}-$ КГ3 - 33,3\% $(\mathrm{p}<0,05)$.

Параметр «Подібність у поглядах подружжя» у чоловіків ОЕ-КГА 1 - 60,0\%, ОЕКГА2 - 67,7\%, ОЕ-КГА3 - 60,0\% $(\mathrm{p}<0,05)$, у жінок ОЕ-КГА 1 - 46,7\%, ОЕ-КГА2 - 53,3\%, OЕ-КГА 3 - 66,7\% $(\mathrm{p}<0,05)$. У чоловіків ОЕ-
КГ 1 - 33,3\%, ОЕ-КГ $2-40,0 \%$, ОЕ-КГ $3-40,0 \%$, у жінок ОЕ-КГ1 - 46,7\%, ОЕ-КГ2 - 33,3\%, OЕ-КГ3 - 46,7\% $(\mathrm{p}<0,05)$. Параметр «Загальні символи сім'ї» у чоловіків ОЕ-КГА1 - 53,3\%, ОЕ-КГА 2 - 46,7\%, ОЕ-КГА 3 - 60,0\% ( $<<0,05)$, у жінок ОЕ-КГА 1 - 60,0\%, ОЕ-КГА 2 - 60,0\%, $\mathrm{OE}-\mathrm{KГА} 3$ - 53,3\% $(\mathrm{p}<0,05)$. У чоловіків ОЕКГ 1 - 33,3\%, ОЕ-КГ 2 - 46,7\%, ОЕ-КГ3 - 40,0\%, у жінок ОЕ-КГ 1 - 40,0\%, ОЕ-КГ 2 - 46,7\%, OEКГ3 - 46,7\% $(\mathrm{p}<0,05)$.

Параметр «Легкість спілкування» у чоловіків ОЕ-КГА 1 - 53,3\%, ОЕ-КГА 2 - 53,3\%, OEКГА $3-60,0 \%(\mathrm{p}<0,05)$, у жінок ОЕ-КГА $1-60,0 \%$, ОЕ-КГА 2 - 46,7\%, ОЕ-КГА3 - 66,7\% (p<0,05). У чоловіків ОЕ-КГ 1 - 46,7\%, ОЕ-КГ2 - 46,7\%, ОЕ-КГ3 - 53,3\%, у жінок ОЕ-КГ 1 - 40,0\%, OEКГ2 - 40,0\%, ОЕ-КГ3 - 40,0\% (p<0,05). Параметр «Психотерапевтичність спілкування» у чоловіків ОЕ-КГА 1 - 46,7\%, ОЕ-КГА 2 - 60,0\%, ОЕКГА $3-60,0 \%(\mathrm{p}<0,05)$, у жінок ОЕ-КГА $1-53,3 \%$, OЕ-КГА 2 - 60,0\%, ОЕ-КГА3 - 60,0\% $(\mathrm{p}<0,05)$. У чоловіків ОЕ-КГ 1 - 40,0\%, ОЕ-КГ2 - 40,0\%, ОЕ-КГ3 - 46,7\%, у жінок ОЕ-КГ 1 - 40,0\%, OEКГ2 - 46,7\%, ОЕ-КГ3 - 46,7\% (p<0,05). Аналіз спілкування у сім'ях ОЕ-КГА порівняно з ОЕ-КГ встановив, що загалом у ОЕ-КГА існує динаміка 
Таблиця 3

Розподіл респондентів у групах оцінювання ефективності щодо спілкування у сім’ї

\begin{tabular}{|c|c|c|c|c|c|c|c|c|c|c|}
\hline \multirow[t]{2}{*}{ Шкали } & \multirow[t]{2}{*}{$\mathbf{C}$} & \multicolumn{3}{|c|}{ ОЕ-КГА1 } & \multicolumn{3}{|c|}{ ОЕ-КГА2 } & \multicolumn{3}{|c|}{ ОЕ-КГАЗ } \\
\hline & & $\mathbf{N}$ & $\%$ & $\pm \mathbf{m}$ & $\mathbf{N}$ & $\%$ & $\pm \mathbf{m}$ & $\mathbf{N}$ & $\%$ & $\pm \mathbf{m}$ \\
\hline \multirow[t]{2}{*}{ Довіра у спілкуванні } & $\mathrm{Y}$ & 9 & 60,0 & 4,9 & 9 & 60,0 & 4,9 & 10 & 66,7 & 4,7 \\
\hline & Ж & 8 & 53,3 & 5,0 & 9 & 60,0 & 4,9 & 9 & 60,0 & 4,9 \\
\hline \multirow{2}{*}{$\begin{array}{l}\text { Взаємоповага між } \\
\text { подружжям }\end{array}$} & $\mathrm{Y}$ & 7 & 46,7 & 5,0 & 10 & 66,7 & 4,7 & 8 & 53,3 & 5,0 \\
\hline & Ж & 8 & 53,3 & 5,0 & 9 & 60,0 & 4,9 & 10 & 66,7 & 4,7 \\
\hline \multirow{2}{*}{$\begin{array}{l}\text { Подібність у поглядах } \\
\text { подружжя }\end{array}$} & $\mathrm{Y}$ & 9 & 60,0 & 4,9 & 10 & 66,7 & 4,7 & 9 & 60,0 & 4,9 \\
\hline & Ж & 7 & 46,7 & 5,0 & 8 & 53,3 & 5,0 & 10 & 66,7 & 4,7 \\
\hline \multirow[t]{2}{*}{ Загальні символи сім’ї } & $\mathrm{Y}$ & 8 & 53,3 & 5,0 & 7 & 46,7 & 5,0 & 9 & 60,0 & 4,9 \\
\hline & Ж & 9 & 60,0 & 4,9 & 9 & 60,0 & 4,9 & 8 & 53,3 & 5,0 \\
\hline \multirow[t]{2}{*}{ Легкість спілкування } & Ч & 8 & 53,3 & 5,0 & 8 & 53,3 & 5,0 & 9 & 60,0 & 4,9 \\
\hline & Ж & 9 & 60,0 & 4,9 & 7 & 46,7 & 5,0 & 10 & 66,7 & 4,7 \\
\hline \multirow{2}{*}{$\begin{array}{l}\text { «сихотерапевтичність» } \\
\text { спілкування }\end{array}$} & $\mathrm{Y}$ & 7 & 46,7 & 5,0 & 9 & 60,0 & 4,9 & 9 & 60,0 & 4,9 \\
\hline & Ж & 8 & 53,3 & 5,0 & 9 & 60,0 & 4,9 & 9 & 60,0 & 4,9 \\
\hline \multirow[t]{2}{*}{ Усього } & $\mathrm{Y}$ & 15 & \multicolumn{2}{|c|}{100,0} & 15 & \multicolumn{2}{|c|}{100,0} & 15 & \multicolumn{2}{|c|}{100,0} \\
\hline & Ж & 15 & \multicolumn{2}{|c|}{100,0} & 15 & \multicolumn{2}{|c|}{100,0} & 15 & \multicolumn{2}{|c|}{100,0} \\
\hline Шкали & $\mathrm{C}$ & \multicolumn{3}{|c|}{ ОЕ-КГА1 } & \multicolumn{3}{|c|}{ ОЕ-КГА2 } & \multicolumn{3}{|c|}{ ОЕ-КГАЗ } \\
\hline \multirow[t]{2}{*}{ Довіра у спілкуванні } & $\mathrm{Y}$ & 6 & 40,0 & 4,9 & 7 & 46,7 & 5,0 & 7 & 46,7 & 5,0 \\
\hline & Ж & 7 & 46,7 & 5,0 & 8 & 53,3 & 5,0 & 7 & 46,7 & 5,0 \\
\hline \multirow{2}{*}{$\begin{array}{l}\text { Взаємоповага між } \\
\text { подружжям }\end{array}$} & Ч & 5 & 33,3 & 4,7 & 4 & 26,7 & 4,4 & 5 & 33,3 & 4,7 \\
\hline & Ж & 6 & 40,0 & 4,9 & 5 & 33,3 & 4,7 & 5 & 33,3 & 4,7 \\
\hline \multirow{2}{*}{$\begin{array}{l}\text { Подібність у поглядах } \\
\text { подружжя }\end{array}$} & $\mathrm{Y}$ & 5 & 33,3 & 4,7 & 6 & 40,0 & 4,9 & 6 & 40,0 & 4,9 \\
\hline & Ж & 7 & 46,7 & 5,0 & 5 & 33,3 & 4,7 & 7 & 46,7 & 5,0 \\
\hline \multirow[t]{2}{*}{ Загальні символи сім’ї } & $\mathrm{Y}$ & 5 & 33,3 & 4,7 & 7 & 46,7 & 5,0 & 6 & 40,0 & 4,9 \\
\hline & Ж & 6 & 40,0 & 4,9 & 6 & 40,0 & 4,9 & 7 & 46,7 & 5,0 \\
\hline \multirow[t]{2}{*}{ Легкість спілкування } & $\mathrm{\Psi}$ & 7 & 46,7 & 5,0 & 7 & 46,7 & 5,0 & 8 & 53,3 & 5,0 \\
\hline & Ж & 6 & 40,0 & 4,9 & 6 & 40,0 & 4,9 & 6 & 40,0 & 4,9 \\
\hline \multirow{2}{*}{$\begin{array}{l}\text { «сихотерапевтичність» } \\
\text { спілкування }\end{array}$} & Ч & 6 & 40,0 & 4,9 & 6 & 40,0 & 4,9 & 7 & 46,7 & 5,0 \\
\hline & Ж & 6 & 40,0 & 4,9 & 7 & 46,7 & 5,0 & 7 & 46,7 & 5,0 \\
\hline \multirow[t]{2}{*}{ Усього } & Ч & 15 & & & 15 & & & 15 & & \\
\hline & Ж & 15 & & & 15 & & & 15 & & \\
\hline
\end{tabular}

ймовірність помилки першого роду, рівень статистичної значимості між показниками: $p<0,05$ (достовірно значущі відмінності); $\mathrm{C}-$ стать

збільшення позитивних відповідей, а пари, які мали більшій стаж сімейного життя, у сукупності 3 адюльтером мали уповільнення відновлення стосунків та нівелювання порушень функціонування родини.

Висновки. Узагальнюючи етап оцінки ефективності комплексної системи сімейного консультування (психокорекції) порушень життєдіяльності родини в разі адюльтеру, зазначаємо, що у респондентів ОЕ-КГА загальна тривожність класифікувалась як слабка або помірна без виражених ознак підвищеної стомлюваності, слабкості, зниження працездатності. Власний стан сприймається критично та усвідомлено без заперечення психологічного конфлікту $(\mathrm{p}<0,05)$. У респондентів $з$ виявленою на перших етапах дослідження невротичною тривожністю наявні зменшення насиченості емоційних переживань щодо адюль- теру, бажання розмовляти на тему адюльтеру, рівний настрій, зменшення явищ адинамії та вегетативно-соматичних порушень $(\mathrm{p}<0,05)$.

Виявлено зміну астенічних проявів, серед яких слід назвати нівелювання дратівливості та «втоми, що не шукає спокою», проте пасивність та порушення сну (поверхневий, тривожний, труднощі засинання й прокидання) збереглися у слабкому ступені вираження $(\mathrm{p}<0,05)$. Істеричне коло реагування змінилося в бік відповідальних паттернів без обвинувачень навколишніх, акцентування уваги на себе, отримання користі від кризи (первинна вигода) та зменшення нарцисових задоволень (вторинна вигода). Поведінка та соматичний стан характеризувалися як спрямовані на «збереження душевного конфлікту» без витіснення у соматичну сферу $(\mathrm{p}<0,05)$. Факторним аналізом виявлено зниження сома- 
тогенного психологічного реагування, а саме тривоги й астенії; власне істеричне реагування; депресивно-фобічний регістр (вегетативні прояви) $(\mathrm{p}<0,05)$. Респонденти виявляли здатність визнавати та справлятися 3 наявними комплексами, самостійно вирішувати проблеми, кількість яких суб'єктивно (зі слів респондентів) значно зменшилася $(\mathrm{p}<0,05)$. Респонденти відзначали поліпшення відносин та спілкування у родині, особливо у тих парах, які мали меншій стаж браку. Проте пари, які мали більшій стаж сімейного життя, у сукупності 3 адюльтером мали уповільнення відновлення стосунків та меншу динаміку відновлення родинної взаємодії $(\mathrm{p}<0,05)$. Перспективи подальшого дослідження у цьому напрямі передбачають науковий пошук психосоціальних аспектів комунікативних бар'єрів в українських родинах в разі адюльтеру та їх можливого впливу на ефективність програми сімейного консультування.

\section{ЛIТЕРАТУРА}

1. Оліфірович Н.І., Зінкевич-Куземкіна Т.А., Велента Т.Ф. Психологія сімейних криз. Санкт-Петербург : Мова, 2006. 360 с.

2. Эйдемиллер Э.Г., Юстицкий В.В. Психология и психотерапия семьи. Санкт-Петербург : Питер, 2008. $672 \mathrm{c}$.

3. Мєшковська О.А. Варіанти, форми і психокорекція дезадаптації подружньої пари при позашлюбних зв'язках і венеричних захворюваннях жінок : автореф. дис. ... канд. мед. наук : спец. 19.00.04 «Медична психологія»; ХМАПО МОЗ України. Харків, 2005. 27 с.

4. Кришталь В.В., Андрух Г.П. Сексуальная гармония супружеской пары. Харьков : Велес, 1996. 160 с.

5. Пріб Х., Бондар С. Психологічні та психоемоційні проблеми порушення життєдіяльності сім'ї при різних стилях сімейної взаємодії. Psychological Prospects Journal. 2019. № 34. C. 206-218. DOI: https://doi.org/10.29038/2227-1376-2019-34-206-218.

6. Практическая психодиагностика. Методики и тесты : учебное пособие / под ред. Д.Я. Райгородского. Самара : Бахрах-М, 2001. 672 с.

7. Фетіскін Н.П., Козлов В.В., Мануйлов Г.М. Діагностика комплексу меншовартості. Соціально-психологічна діагностика розвитку особистості та малих груn. Москва : Інститут психотерапії, 2002. С. 267.

8. Алешина Ю.Е. Индивидуальное и семейное психологическое консультирование. 2-е изд. Москва : Независимая фирма «Класс», 1999. 208 с.

9. Бююль А., Цефель П. SPSS: искусство обработки информации. Анализ статистических данных и восстановление скрытых закономерностей. Санкт-Петербург : ДиаСофтЮП, 2002. 608 с.

\section{REFERENCES}

1. Olifirovich N.I., Zinkevich-Kuzemkina T.A., Velenta T.F. (2006) Psykhologhija simejnykh kryz [Psychology of family crises]. Sankt-Peterburg: Rech (in Russian).

2. Eydemiller E.G., Yustitskiy V.V. (2008). Psikhologiya i psikhoterapiya sem'i [Psychology and psychotherapy of the family]. Sankt-Peterburg: Piter (in Russian).

3. Mieshkovska O.A. (2005). Varianty, formy i psykhokorekcija dezadaptaciji podruzhnjoji pary pry pozashljubnykh zvjazkakh i venerychnykh zakhvorjuvannjakh zhinok [Variants, forms and psychocorrection of maladaptation of a married couple in extramarital affairs and sexually transmitted diseases in women]. (PhD Thesis). Kharkiv: KhMAPO.

4. Krishtal' V.V., Andrukh, G.P. (1996) Seksual'naya garmoniya supruzheskoy pary [Sexual harmony of a married couple]. Kharkiv: Veles (in Russian).

5. Prib H., Bondar S. (2019). Psychological and pcychoemotional disorders of family functioning [Psykhologhichni ta psykhoemocijni problemy porushennja zhyttjedijaljnosti sim'ji pry riznykh styljakh simejnoji vzajemodiji]. Psychological Prospects Journal, vol. 34, https://doi.org/10.29038/2227-1376-2019-34-206-218.

6. Raygorodskiy D.Ya. (2001). Prakticheskaya psihodiagnostika. Metodiki i testyi. Uchebnoe posobie [Practical psychodiagnostics. Techniques and tests]. Samara: Bahrah-M (in Russian).

7. Fetiskin N.P., Kozlov V.V., Manujlov G.M. (2002) Diaghnostyka kompleksu menshovartosti [Diagnosis of the inferiority complex]. Socialjno-psykhologhichna diaghnostyka rozvytku osobystosti ta malykh ghrup [Socio-psychological diagnosis of personality development and small groups]. Moscow: Institut psihoterapij, p. 267.

8. Aleshina Y.E. (1999) Individual'noe i semeynoe psikhologicheskoe konsul'tirovanie [Individual and family psychological counseling]. Moscow: Nezavisimaya firma "Klass" (in Russian).

9. Byuyul A., Tsefel P. (2002). SPSS: iskusstvo obrabotki informatsii. Analiz statisticheskikh dannykh i vosstanovlenie skrytykh zakonomernostey [SPSS: the art of information processing. Analysis of statistical data and restoration of hidden patterns]. Sankt-Peterburg: DiaSoftYuP (in Russian). 